Eur. J. Clin. Chem. Clin. Biochem.

Vol. 32, 1994, pp. 767-772

(C) 1994 Walter de Gruyter \& Co. Berlin - New York

\title{
Flow Injection Determination of Glutamate in Human Serum and Rat Brain Samples with Immobilized Glutamate Oxidase and Glutamate Dehydrogenase Reactors ${ }^{1}$ )
}

\author{
By C. D. Stalikas, M. I. Karayannis and Stella M. Tzouwara-Karayanni \\ Department of Chemistry, University of Ioannina, Ioannina, Greece
}

(Received January 19/April 25/July 18, 1994)

Summary: Two methods are proposed for the determination of regional concentrations of glutamate in the rat brain as well as in human serum.

Glutamate oxidase was immobilized on non-porous glass beads and glutamate dehydrogenase was immobilized on glass derivatives. These supports were employed for the construction of Single Bead String Reactors and Packed Bed Reactors, respectively, which in turn were linked to Flow Injection Analysis systems with either photometric or fluorometric detection. Analytical working curves are linear in the range 1-200 $\mu \mathrm{mol} / \mathrm{l}$ for packed bed reactors and $10-500 \mathrm{mmol} / \mathrm{l}$ for single bead string reactors. The samples were pretreated depending on their origin and the applied measuring system. Optimal dilution factors were established for the two techniques. Optimal dilution ratios were established and the influence of several added substances was investigated. Recovery and method comparison studies including high performance liquid chromatography verified the accuracy of the proposed methods. Results from within-day and between-day measurements gave relative standard deviations of 4.7 and $5.9 \%$ for serum samples and 2.5 and $4.0 \%$ for brain samples, respectively.

\section{Introduction}

Glutamic acid is considered to be an important neurotransmitter in the mammalian central nervous system (1) and the suspicion that it may play a significant role in the aetiology and pathophysiology of a number of neurological and psychiatric disorders $(2,3)$ has generated extra interest in the study of this amino acid. Glutamic acid concentrations are significantly higher in neoplastic ascites than in cardial ascites (4). The increasing trend toward the development of analytical methods for reliable and accurate determination of low glutamic acid concentration in very small samples is therefore not surprising. These methods include enzymatic measurements with glutamate oxidase and glutamate dehydrogenase $\left.{ }^{2}\right)$, either alone $(5-7)$ or in combination with other

\footnotetext{
1) Funding: STRIDE HELLAS - 33 PROJECT

2) Enzymes:

Glutamate dehydrogenase (EC 1.4.1.3)

Glutamate oxidase (EC 1.4.3.11)
}

enzymes (8-11), HPLC $(12,13)$ and gas chromatography-mass spectrometry $(14,15)$. All these methods have been applied for the determination of glutamic acid in biological samples with relative success, but they are not exempt from drawbacks such as the use of complicated and/or expensive equipment and the lack of accuracy at low concentrations of glutamic acid in complex matrices. They also are time consuming, tedious and therefore unsuitable for the rapid routine analysis of large numbers of samples.

In this presentation two methods for the determination of glutamic acid in human serum and rat brain were used, based on previous investigations $(16,17)$.

\section{Materials and Methods}

Reagents

All the chemicals used were of analytical-reagent grade and the solutions were prepared in doubly distilled water. Glutamate oxi- 
dase (EC 1.4.3.1) from Streptomyces sp., $5 \mathrm{U} / \mathrm{mg}$ solid was a gift from Yamasa Shoyu (Chiba-Ken, Japan). Glutamate dehydrogenase (EC 1.4.1.3) $120 \mathrm{U} / \mathrm{mg}$ enzyme protein from beef liver and nicotinamide adenine dinucleotide (NAD ${ }^{+}$grade $\mathrm{I}, 100 \%$ ) were purchased from Boehringer Mannheim (Bochringer Mannheim Biochemica, Germany). The rest of the chemical compounds and the enzyme supports (controlled pore glass derivatives and non-porous glass bends) for the immobilization, were purchased from Sigma (St Louis, MO, USA). Glutamic acid standard solutions were prepared from a $0.01 \mathrm{~mol} / \mathrm{l}$ stock solution by appropriate dilutions.

\section{Instrumentation}

Two flow injection analysis systems, using either single bead string reactors consisting of non-porous glass beads with immobilized glutamate oxidase, or packed bed reactors with immobilized glutamate dehydrogenase on Aminopropyl-controlled pore glass and isothiocyanate-controlled pore glass, were used in connection with photometric or fluorometric detection, depending on the employed enzyme. In the second of these enzymatic sytems the NADH generated is proportional to the original concentration of glutamic acid and is measured fluorometrically at $460 \mathrm{~nm}$ after its excitation at $340 \mathrm{~nm}$. Three values were obtained for each sample, one spectrophotometrically and two fluorometrically, since the two controlled pore glass reactors were used separately in the flow injection analysis. The flow injection measurements were performed with a home made unit used in two different arrangements. The flow injection analysis set-up consists of a four-way pneumatically actuated injection valve, an eight channel peristaltic pump and a home made filter spectrophotometer or a spectrofluorimeter (RF-551, Shimadzu, Japan) equipped with low volume flow-through cells $(2 \mu \mathrm{l}$ and $12 \mu \mathrm{l}$, respectively). The experimental set-ups, which are shown in figure 1, can be thermostated with a controlled water bath. Data collection and processing was performed with an IBMcompatible personal computer and a software written in Microsoft Q-Basic. The interface unit was an RTL 800/815 multifunction input-output board.

\section{Preparation and treatment of the samples}

The rats were killed by decapitation and the brains were removed. The middle brain, the cerebral cortex, the hypothalamus and the striatum together with substantia nigra were dissected and rapidly dropped into liquid nitrogen to minimize post mortem changes. Amounts of $25-30 \mathrm{mg}$ of the sample were homogenized in $2.0 \mathrm{ml}$ of $80 \%$ cold ethanol in water (normally used for proteinaceous tissues) under ultrasonication at $45 \mathrm{~W}$ for three minutes. The suspension was centrifuged for $10 \mathrm{~min}$ at $1370 \mathrm{~g}$, then the supernatant combined with the washings $(3.5 \mathrm{ml}$ total volume) was concentrated to dryness under reduced pressure. To the residue were added $1 \mathrm{ml}$ of $0.1 \mathrm{~mol} / 1$ phosphate buffer $\mathrm{pH} 8.0$ and the resultant suspension was filtered through a $0.45 \mu \mathrm{m}$ membrane filter to remove the particulate matter.

The human serum samples were obtained from patients of the Ioannina University Hospital. Three different methods for the deproteinization of serum samples were employed including either chemical or physical techniques.

Method (a): Serum sample $(500 \mu \mathrm{l})$ was mixed with $80 \mu \mathrm{l}$ of a 150 $\mathrm{g} / \mathrm{l}$ zinc sulphate and $300 \mu \mathrm{l}$ of a $50 \mathrm{~g} / \mathrm{l}$ barium hydroxide. The mixture was centrifuged and the supernatant was analysed after appropriate dilution and ultrafiltration through a membrane with a nominal weight cut off of $M_{\mathrm{r}} 30000$ (Millipore, Bedford, MA 01730 USA) for fluid clarification. An excess of the reagents was necessary for the completion of the precipitation of the proteins. The time needed to prepare the filtrate was $10 \mathrm{~min}$.

Method (b): Serum sample $(400 \mu \mathrm{l})$ was applied to a Sephadex G25 superfine column (Pharmacia, Uppsala, Sweden, $1.5 \mathrm{~cm} \times 4.8$ $\mathrm{cm})$. The glutamic acid was eluted with buffer solution, $0.1 \mathrm{~mol} / \mathrm{l}$ phosphate $\mathrm{pH} 8.0$. The analyte appears quantitatively between 2.5 and $8.0 \mathrm{ml}$ of the elution volume. This procedure takes only about $5 \mathrm{~min}$.

Method (c): The serum samples were diluted $1: 20$ or $1: 7$ (depending on the applied method, photometric or fluorimetric) with phosphate buffer and proteins were removed by ultrafiltration through a membrane with a nominal weight cut off of $M_{\mathrm{r}} 10000$. This procedure takes about $15 \mathrm{~min}$ for the preparation of $300 \mu \mathrm{l}$ of a protein-free solution.

\section{Analytical procedure}

In the case of photometric detection the procedure entails injection of the sample into the carrier stream and the production of $\mathrm{H}_{2} \mathrm{O}_{2}$ on the single bead string reactor containing the immobilized glutamate oxidase. The reaction mixture meets the Trinder reagent (18) at the output of enzymatic reactor and flows through a second single bead string reactor $(40 \mathrm{~cm} \times 0.8 \mathrm{~mm})$, filled with untreated glass beads, which allows sufficient time for the completion of the reaction. The maximum of the absorbance-time curve, $A_{\max }$, is measured automatically at $510 \mathrm{~nm}$ (fig. 1). The working $\mathrm{pH}$ of the system is 7.8 , the over-all flow rate $0.25 \mathrm{ml} / \mathrm{min}$ and the concentrations of aminoantipyrine, 3,5-dichloro-2-hydroxybenzenesulphonic acid and peroxidase are $0.4 \mathrm{mmol} / 1,1.2 \mathrm{mmol} / 1$ and $440000 \mathrm{U} / 1$, respectively. The absorbances measured for the construction of the calibration curve were in the range $0.030-0.850$. The optimal working conditions as well as the specificity of the analytical method have been well established in a previous publication (16).

When fluorescence detection is used, the circulating solution with the sample is driven to a $15 \mathrm{~cm}$ mixing single bead string reactor positioned after the intake of $\mathrm{NAD}^{+}$. The mixture then passes through the immobilized glutamate dehydrogenase reactor. The peak height of the fluorescence curve is used for the quantification of glutamic acid. The optimal $\mathrm{pH}$ of the system is 8.0 , the overall flow rate $0.32 \mathrm{ml} / \mathrm{min}$ and the final concentration of $\mathrm{NAD}^{+} 3.2$ $\mathrm{mmol} / \mathrm{l}$. A detailed description of the immobilization procedure is given elsewhere (17).

The sampling throughput for both systems is 40 samples per hour and the required volume for each replicate is $55 \mu \mathrm{l}$.

\section{Results and Discussion}

The enzymatic methods depend on the specificity of the enzyme and the secondary reactions involved. Table 1 shows the results of the interference study with 15 different compounds. Glutathione, uric acid, ascorbic acid (and other reducing compounds, data not shown) interfere seriously with the photometric method as they usually do in all procedures involving peroxidase-hydrogen peroxide systems (19). Ascorbic acid is partly auto-oxidized in phosphate buffer to dehydroascorbic acid. The response of the fluorimetric system is not affected by the presence of $\alpha$-ketoghutaric acid, $\mathrm{NH}_{4}^{+}$and folic acid in concentrations reported in table 1 , since their normal concentrations in human serum are ca. $6 \mu \mathrm{mol} / 1,80 \mu \mathrm{mol} / 1$ and 30 nmol/l, respectively (20).

Deproteinization of the samples was necessary in order to avoid any high blanks and double peaks during the measurements. Most of the protein precipitants either cause undesirable effects that decrease the lifetime of the reactors, or they cause proteolysis with release of 


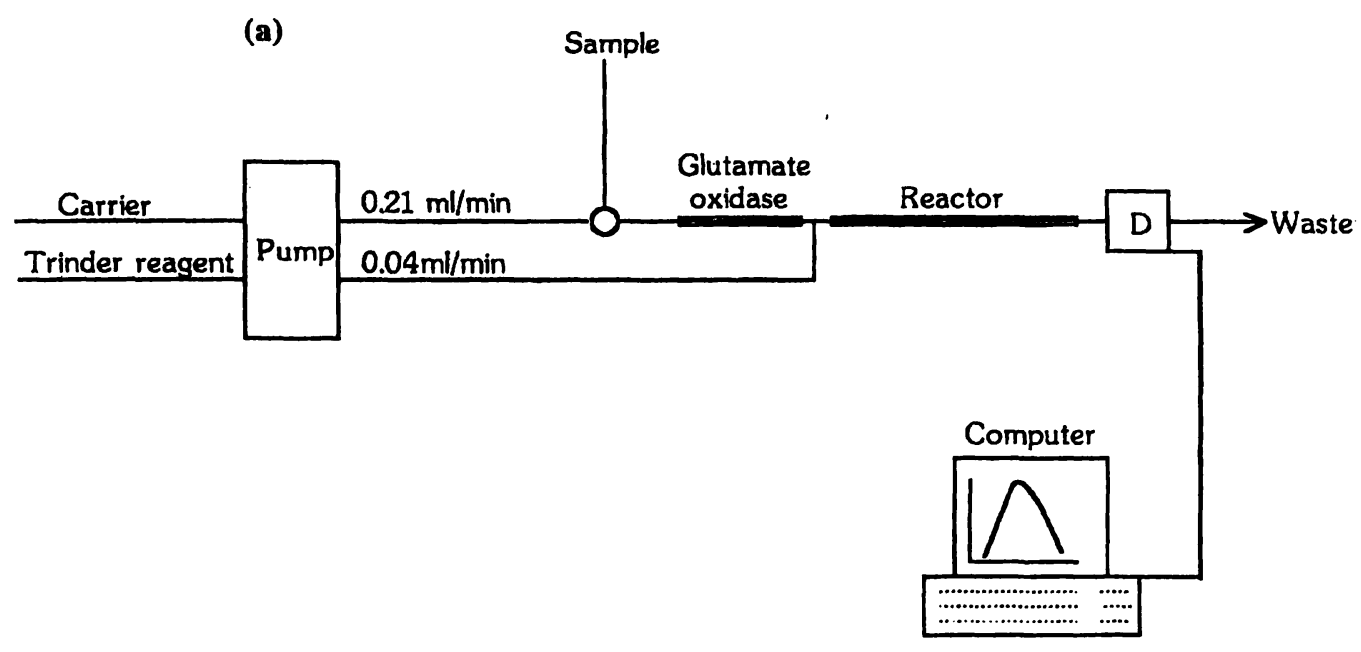

(b)

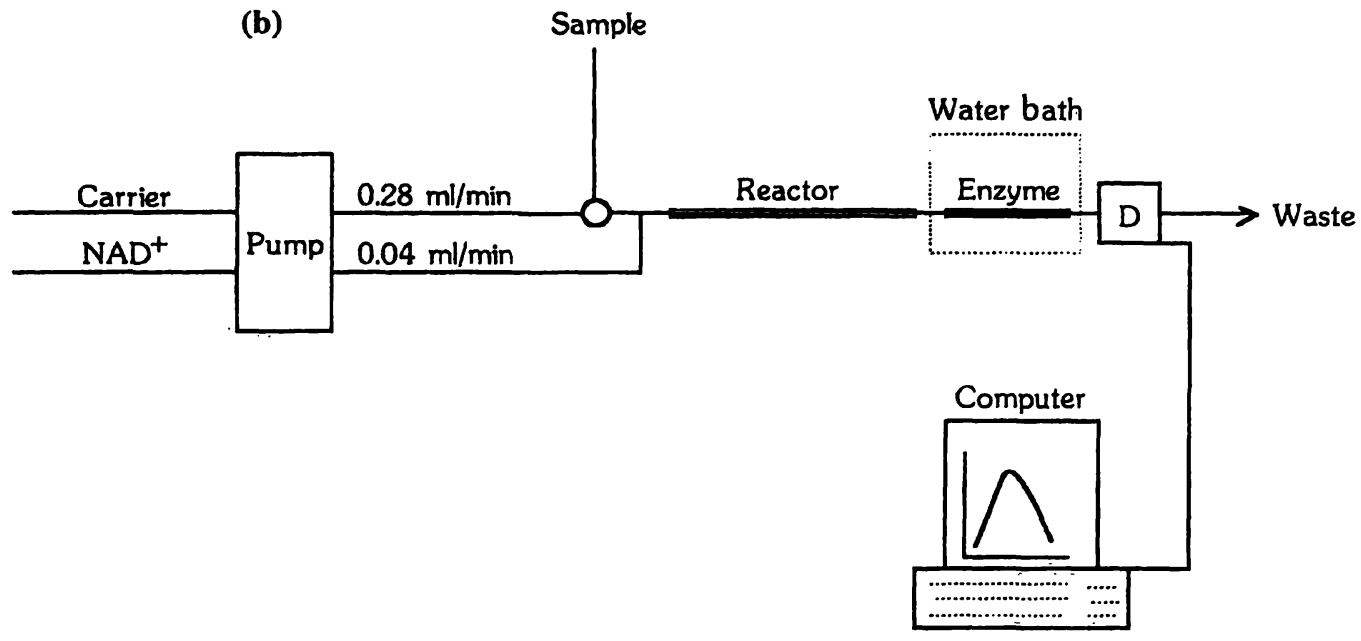

Fig. 1 Flow injection assay set-up for glutamic acid determination:
(a) Manifold for photometric detection,
(b) Manifold for fluorometric detection,

amino acids, which therefore rise to abnormal concentrations in the serum samples. Precipitation with sulphosalicylic acid causes losses of about $20 \%$ for all amino acids (21) while the background absorbance in the filtrates reaches its highest value during precipitation with trichloroacetic acid and sodium tungstate (22).

The well established coprecipitation (23) applied in method (a) was further exploited during our work: efficient removal of proteins and the non-glucose reducing compounds is a critical condition for the implementation of the photometric method and the use of single bead string reactor bearing the glutamate oxidase. Glutamate dehydrogenase on the other hand, is susceptible to $\mathrm{Ba}^{2+}$ and $\mathrm{Zn}^{2+}$ interference.

Ultrafiltration and gel filtration are simpler and faster approaches for the preparation of protein-free solutions. The dilutions of the serum samples prior to their ultrafiltration reduces significantly the time for one analysis,
Reactor: Single Bead String-Plain Reactor (i. e. reactor filled with untreated glass beads),

D: Detector, Enzyme: glutamate dehydrogenase.

thus minimizing the probability of hydrolysis of serum proteins or of glutamine breakdown (24). The final preparation was ultrafiltered and determined by the fluorometric method. In this case, ultrafiltration proved to be an ideal technique and the recovery of the added glutamic acid was almost complete.

Based on the results of the above mentioned investigation, the precipitation with zinc sulphate was applied for the determination of glutamic acid in serum samples taken from seven adult patients. All alternative methods for the removal of proteins from the serum samples proved to be unsuccessful. An explanation for this is probably the presence of reducing interferences in most of the samples. In contrast, the above assay was feasible, because ultrafiltration and gel filtration remove any optical interference prior to the fluorometry. The results given in table 2 substantiate the work described above. The gel filtration procedure, which results in a dilution 
Tab. 1 Effects of several compounds on the assay of glutamic acid. Standard solutions of glutamate, $100 \mu \mathrm{mol} / \mathrm{l}$ for the photometric and $50 \mu \mathrm{mol} / 1$ for the fluorometric manifold, were used. The concentration of each tested compound was $1 \mathrm{mmol} / \mathrm{l}$.

\begin{tabular}{lll}
\hline Interfering compound & \multicolumn{2}{l}{ Relative response } \\
\cline { 2 - 3 } & $\begin{array}{ll}\text { Photometric } \\
\text { method }\end{array}$ & $\begin{array}{l}\text { Fluorometric } \\
\text { method }\end{array}$ \\
\hline None & 100 & 100 \\
$L$-Methionine & 100 & 103 \\
L-Norvaline & 100 & 112 \\
$\gamma$-Aminobutyric acid & 100 & 100 \\
Heparin & 102 & 102 \\
Citrate & 101 & 82 \\
Cholesterol & 100 & 98 \\
Urea & 98 & 99 \\
Uric acid & 71 & 99 \\
Glutathione & 46 & 104 \\
Glutamic ester $^{\mathrm{a}}$ & 100 & 102 \\
Peptide $1^{\text {b }}$ & 101 & 105 \\
Peptide $2^{\mathrm{c}}$ & 101 & 106 \\
Folic acid $^{\mathrm{d}}$ & 100 & 103 \\
a-Ketoglutaric acid $^{\mathrm{e}}$ & 100 & 98 \\
Ammonium ion $^{\mathrm{f}}$ & 100 & 99 \\
\hline
\end{tabular}

a $\mathrm{HGlu}(\mathrm{OMe}) \mathrm{OH}$

b Glu-Ile-Asn-Arg-Pro-Asp-Tyr-Leu-Asp-Phe-Ala

c Ala-Asn-Pro-Glu-Ala-Glu-Gly-Gly-Leu-Glu-Trp-Leu-Asn-ArgArg-Ala

d $100 \mathrm{nmol} / \mathrm{l}$

e $30 \mu \mathrm{mol} / \mathrm{l}$

f $300 \mu \mathrm{mol} / \mathrm{l}$

Tab. 2 Determination of glutamic acid in serum samples by the two proposed methods and the HPLC method, in $\mathrm{mmol} / \mathrm{l}$. The results for the fluorometric methods were obtained after ultrafiltration of the samples. All the results are the average of triplicates and the errors range from 0.01 to $0.03 \mathrm{SD}$.

\begin{tabular}{|c|c|c|c|c|}
\hline \multirow[t]{3}{*}{ Sample } & \multicolumn{4}{|l|}{ Method } \\
\hline & \multirow{2}{*}{$\begin{array}{l}\text { Photo- } \\
\text { metric } \\
\text { Single } \\
\text { bead } \\
\text { string } \\
\text { reactor }\end{array}$} & \multicolumn{2}{|c|}{ Fluorometric } & \multirow{2}{*}{$\begin{array}{l}\text { HPLC } \\
\text { (15) }\end{array}$} \\
\hline & & $\begin{array}{l}\text { Amino- } \\
\text { propyl- } \\
\text { controlled } \\
\text { pore glass }\end{array}$ & $\begin{array}{l}\text { Isothio- } \\
\text { cyanate- } \\
\text { controlled } \\
\text { pore glass }\end{array}$ & \\
\hline 1 & 0.18 & 0.19 & 0.18 & 0.19 \\
\hline 2 & 0.12 & 0.12 & 0.12 & 0.11 \\
\hline 3 & 0.39 & 0.38 & 0.39 & 0.39 \\
\hline 4 & 0.17 & 0.17 & 0.17 & 0.16 \\
\hline 5 & 0.37 & 0.37 & 0.37 & 0.37 \\
\hline 6 & 0.36 & 0.37 & 0.38 & 0.37 \\
\hline 7 & 0.21 & 0.22 & 0.21 & 0.23 \\
\hline
\end{tabular}

of the sample $1: 13.75$, gave results very close to the obtained with the above procedure. If necessary, higher dilutions were performed, to attain almost undetectable blank values in the flow injection measurements.

In the case of brain tissue no protein removal or any other treatment was necessary, since no blank values were observed after the dilution of the liquid sample extracted by the method given above. The photometric method does not suffer from the above mentioned interferences. Table 3 gives results of the regional concentration of glutamic acid obtained by applying the two methods. All the concentrations of glutamic acid found in the serum samples and these from different regions of brain are in good agreement with those obtained by the HPLC method, omitting the hydrolysis step (25).

The within-day results and between-day reproducibility studies in two representative samples (serum sample and brain tissue) gave the relative standard deviations for the two methods which appear in table 4.

The accuracy of the proposed methods was also verified by recovery studies, in which standard glutamic acid solutions were added to several samples. Recoveries of $93-104 \%$ were attained as shown in table 5 .

The proposed methods can also be applied for the determination of glutamic acid in blood plasma after adding heparin as anticoagulant to the blood samples.

In conclusion, the two proposed analytical procedures seem to be sensitive, reproducible, accurate and relatively rapid for the determination of glutamic acid in serum and brain tissue. The assay can be carried out with simple and easily available instrumentation. Compared with the well known HPLC methods, our methods offer simplicity and low cost, and they are well suited to the routine analysis of large numbers of samples (40 against 2 samples per hour), without any derivatization. The reactors are stable when kept in a refrigerator in buffered phosphate, when not in use. They can be used for more than 3000 runs and retain $75 \%$ of their initial activity after a working period of three months. The detection limits of the proposed methods are comparable

Tab. 3 Glutamic acid concentrations in $\mu \mathrm{mol} / \mathrm{g}$ of wet tissue measured in several regions of the rat brain. The data presented are the means of triplicate measurements by each of the proposed methods. The SD of the means ranges from 0.1 to 0.3 .

\begin{tabular}{|c|c|c|c|c|}
\hline \multirow[t]{3}{*}{ Region } & \multicolumn{4}{|l|}{ Method } \\
\hline & \multirow{2}{*}{$\begin{array}{l}\text { Photo- } \\
\text { metric } \\
\text { Single } \\
\text { bead } \\
\text { string } \\
\text { reactor }\end{array}$} & \multicolumn{2}{|c|}{ Fluorometric } & \multirow{2}{*}{$\begin{array}{l}\text { HLPC } \\
(15)\end{array}$} \\
\hline & & $\begin{array}{l}\text { Amino- } \\
\text { propyl- } \\
\text { controlled } \\
\text { pore glass }\end{array}$ & $\begin{array}{l}\text { Isothio- } \\
\text { cyanate- } \\
\text { controlled } \\
\text { pore glass }\end{array}$ & \\
\hline Cerebral cortex & 10.1 & 9.3 & 9.1 & - \\
\hline Hypothalamus & 6.3 & 6.5 & 6.7 & 6.6 \\
\hline Middle brain & 12.0 & 12.5 & 12.7 & 12.4 \\
\hline $\begin{array}{l}\text { Striatum- } \\
\text { Substantia nigra }\end{array}$ & 9.8 & 10.3 & 10.3 & - \\
\hline
\end{tabular}


Tab. 4 Within-day and between-day relative standard deviations (CV) for the two methods and two representative samples.

\begin{tabular}{|c|c|c|c|c|}
\hline \multirow[t]{2}{*}{ Sample } & \multicolumn{2}{|c|}{ Within-day CV (\%) } & \multicolumn{2}{|c|}{ Between-day CV (\%) } \\
\hline & $\begin{array}{l}\text { Photometric } \\
\text { method }\end{array}$ & $\begin{array}{l}\text { Fluorometric } \\
\text { method }\end{array}$ & $\begin{array}{l}\text { Photometric } \\
\text { method }\end{array}$ & $\begin{array}{l}\text { Fluorometric } \\
\text { method }\end{array}$ \\
\hline $\begin{array}{l}\text { Serum }(0.37 \mathrm{mmol} / \mathrm{l}) \\
\text { Middle Brain }(12 \mu \mathrm{mol} / \mathrm{g})\end{array}$ & $\begin{array}{l}5.1(n=7) \\
2.4(n=5)\end{array}$ & $\begin{array}{l}4.0(n=7) \\
2.7(n=5)\end{array}$ & $\begin{array}{l}6.0(n=6) \\
4.4(n=4)\end{array}$ & $\begin{array}{l}5.8(n=6) \\
3.6(n=4)\end{array}$ \\
\hline
\end{tabular}

Tab. 5 Recovery of $L$-glutamic acid added to the serum and brain samples analysed in tables 2 and 3 , respectively.

\begin{tabular}{|c|c|c|c|c|c|c|c|}
\hline \multirow[t]{3}{*}{ Sample, unit } & \multicolumn{7}{|l|}{ Method } \\
\hline & \multicolumn{4}{|c|}{ Photometric } & \multicolumn{3}{|c|}{$\begin{array}{l}\text { Fluorometric with } \\
\text { Aminopropyl-controlled pore glass }\end{array}$} \\
\hline & $\begin{array}{l}\text { Added } \\
\mathrm{mmol} / \mathrm{l}\end{array}$ & $\begin{array}{l}\text { Taken* } \\
\mathrm{mmol} / 1\end{array}$ & $\begin{array}{l}\text { Found } \\
\mathrm{mmol} / 1\end{array}$ & $\begin{array}{l}\text { Recovery } \\
\%\end{array}$ & $\begin{array}{l}\text { Taken* } \\
\text { mmol/l }\end{array}$ & $\begin{array}{l}\text { Found } \\
\mathrm{mmol} / 1\end{array}$ & $\begin{array}{l}\text { Recovery } \\
\%\end{array}$ \\
\hline Serum $1, \mathrm{mmol} / 1$ & 0.15 & 0.33 & 0.31 & 94 & 0.34 & 0.34 & 100 \\
\hline Serum $7, \mathrm{mmol} / 1$ & 0.20 & 0.41 & 0.38 & 93 & 0.42 & 0.41 & 98 \\
\hline Hypothalamus, $\mu \mathrm{mol} / \mathrm{g}$ tissue & 5.0 & 11.3 & 11.3 & 100 & 11.5 & 11.4 & 99 \\
\hline Middle Brain, $\mu \mathrm{mol} / \mathrm{g}$ tissue & 7.0 & 19.0 & 19.7 & 104 & 19.5 & 19.9 & 102 \\
\hline
\end{tabular}

* These concentrations represent the values given in tables 2 and 3 for the respective samples, plus the added amounts (given under "added" in the table).

with those of the majority of the HPLC techniques (almost $0.3 \mu \mathrm{mol} / \mathrm{l}$ ) and adequate for the applications given above. The enzymatic methods with the soluble enzymes are not automated and they are uneconomic, because of the irreversible consumption of the enzymes.

\section{References}

1. Fonnum, F., Engelsen, B., Walker, J. E. \& Kvale, I. (1984) Glutamate: A neurotransmitter in mammalian brain. J. Neurochem. $42,1-11$.

2. Takasaki, Y. (1978) Studies on brain lesions by administration of monosodium $L$-glutamate to mice. Toxicology 9, 307-312.

3. Engelsen, B., Fosse, V. \& Fonnum, F. (1987) The acute effect of ammonium acetate on levels of amino acids in the intact and decorticated rat neostriatum. J. Neurochem. 48, 741-744.

4. Hirschberger, J., Goldberg, M. \& Sauer, G. U. (1993) Glutamine and glutamate in ascitic fluid of dogs. Eur. J. Clin. Chem. Clin. Biochem. 31, 103-106.

5. Graham, T. L. \& Aprison, H. M. (1966) Fluorimetric determination of aspartate, glutamate, and $\gamma$-aminobutyrate in nerve tissue ưsing enzymatic methods. Anal. Biochem. 15, 487-497.

6. Mora, M. P., Franco, M. J., Rocio, S. \& Escovar, R. R. (1989) A glutamate dehydrogenase-based method for the assay of $L$ glutamic acid: Formation of pyridine nucleotide fluorescent derivatives. Anal. Biochem. 180, 248.

7. Yao, T., Kobayashi, N. \& Wasa, T. (1990) Flow injection analysis for $L$-glutamate using immobilized $L$-glutamate oxidase: Comparison of an enzyme reactor and enzyme electrode. Anal. Chim. Acta 231, 121-124.

\section{Acknowledgements}

This work was financially supported partly by the "G. STAVROU" foundation and the STRIDE HELLAS - 33 PROJECT. Free samples of glutamate oxidase were kindly provided by $\mathrm{Dr} H$. Kusakabe (Yamasa Shoyu Co., Chiba-Ken, Japan).

The authors wish to express their thanks to Miss Vassiliki Boumba from the Biological Chemistry Laboratory, School of Medicine, for performing the HPLC measurements.

8. Guilbault, G. G., Sadar, S. H. \& McQueen, R. (1969) A fluorimetric enzymic method for the assay of mixtures of organic acids. Anal. Chim. Acta 45, 1-12.

9. Beutler, H.-O. (1985) In: Methods of Enzymatic Analysis (Bergmeyer, H. U., ed.) 3rd Ed., vol. VIII, pp. 369-376, Verlag Chemie, Weinheim, Deerfield Beach/Florida, Basel.

10. Villarta, L. R., Cunningham, D. D. \& Guilbault, G. G. (1991) Amperometric enzyme electrodes for the determination of $L$ glutamate. Talanta $38,49-55$.

11. Girotti, S., Ghini, S., Budini, R., Pistillo, A., Carrera, G., Bovara, R., Piazzi, S., Merighi, R. \& Roda, A. (1992) Bioluminescent flow sensor for $L$-glutamate. Anal. Letters 25, 637652.

12. Lindroth, P. \& Mopper, K. (1979) High performance liquid chromatographic determination of subpicomole amounts of amino acids by precolumn fluorescence derivatization with o-phthaldialdehyde. Anal. Chem. 51, 1667-1674.

13. Heinrikson, L. R. \& Meredith, S. (1984) Amino acids analysis by reverse-phase high performance liquid chromatography: Precolumn derivatization with phenylisothiocyanate. Anal. Biochem. 136, 65-74.

14. Darmaun, D., Manary, M. J. \& Matthews, D. E. (1958) A method for measuring both glutamine and glutamate levels and stable isotopic enrichments. Anal. Biochem. 147, 92-102. 
15. Kapetanovic, I. M., Yonekawa, W. D. \& Kupferberg, H. J. (1987) Determination of 4-aminobutyric acid, aspartate, glutamate and glutamine and their $C$ stable-isotopic enrichment in brain tissue by gas chromatography-mass spectrometry. J. Chromatog. 414, 265-274.

16. Stalikas, C. D., Karayannis, M. I. \& Tzouwara-Karayanni, S. M. (1993) Immobilization of glutamate oxidase on non-porous glass beads. Automated flow injection system for the assay of glutamic acid in food samples and pharmaceuticals. Analyst $118,723-726$.

17. Stalikas, C. D., Karayannis, M. I. \& Tzouwara-Karayanni, S. $M$. Immobilization of glutamate dehydrogenase on glass derivatives. A simple method for the assay of glutamates in real samples with an automated FIA-system. Accepted for publication in Talanta.

18. Barham, D. \& Trinder, P. (1972) An improved colour reagent for the determination of blood glucose by the oxidase system. Analyst 97, 142-145.

19. White-Stevens, R. H. (1982) Interference by ascorbic acid in test systems involving peroxidase. Clin. Chem. 28, 578-595.

20. Kaplan, L. A. \& Pesce, J. A. (1989) Clinical Chemistry (Theory. Analysis and Correlation), 2nd edn. (Stefanie Bircher editor) C. V. Mosby Company, St Louis.
21. Gerritsen, T., Rehberg, M. L. \& Waisman, A. H. (1965) Determination of free amino acids in serum. Anal. Biochem. 11, 460-466.

22. Richard, J. H. \& Berkman, S. (1957) Absorbance of various protein-free filtrates of serum. Clin. Chem. 3, 711-715.

23. Henry, J. R., Cannon, C. D. \& Winkelman, W. J. (1974) Clinical Chemistry. Principles and Technics, 2nd edn. (Bio-Science Laboratories, ed.) pp. 401-403, Harper \& Row, Publishers, Maryland.

24. Gerritsen, T., Rehberg, L. M. \& Waisman, A. H. (1965) On the determination of free amino acids in serum. Anal. Biochem. 11, 460-466.

25. Ebert, F. R. (1986) Amino acid analysis by HPLC: Optimized conditions for chromatography of phenylthiocarbamyl derivatives. Anal. Biochem. 154, 431-435.

Stella M. Tzouwara-Karayanni

Department of Chemistry

University of Ioannina

Ioannina 45110

Greece 